\title{
Enhanced Production of Cellulase from Pineapple Waste by Response Surface Methodology
}

\author{
P. Saravanan, R. Muthuvelayudham, and T. Viruthagiri \\ Department of Chemical Engineering, Annamalai University, Annamalainagar 608002, Tamilnadu, India \\ Correspondence should be addressed to P. Saravanan; vidhyasaravanan11@gmail.com
}

Received 31 August 2012; Revised 5 November 2012; Accepted 11 November 2012

Academic Editor: Tingyue Gu

Copyright (C) 2013 P. Saravanan et al. This is an open access article distributed under the Creative Commons Attribution License, which permits unrestricted use, distribution, and reproduction in any medium, provided the original work is properly cited.

\begin{abstract}
Optimization of the media components for cellulase production using Trichoderma reesei was carried out. The optimization of cellulase production using pineapple waste as substrate was performed with statistical methodology based on experimental designs. The screening of nutrients and their influence on the cellulase production was studied using a Plackett-Burman design. Avicel, soybean cake flour, $\mathrm{KH}_{2} \mathrm{PO}_{4}$, and yeast extract were found to have the positive influence for the production of cellulase. The selected components were optimized using response surface methodology. The optimum concentrations are avicel: $26.5 \mathrm{~g} / \mathrm{L}$, soybean cake flour: $22.5 \mathrm{~g} / \mathrm{L}, \mathrm{KH}_{2} \mathrm{PO}_{4}: 4.5 \mathrm{~g} / \mathrm{L}$, and yeast extract: $12.3 \mathrm{~g} / \mathrm{L}$. A maximum cellulase activity of $8.61 \mathrm{IU} / \mathrm{mL}$ was obtained under the optimized medium in the validation experiment.
\end{abstract}

\section{Introduction}

Enzymatic hydrolysis of cellulose to glucose is carried out by the enzyme cellulase, a multienzyme complex made up of several proteins. Cellulases are enzymes synthesized by a large diversity of microorganisms including both fungi and bacteria during their growth on cellulosic material. These microorganisms can be aerobic, anaerobic, mesophilic, or thermophilic. Among them, the genera of Clostridium, Cellulomonas, Thermomonospora, Trichoderma, and Aspergillus are the most extensively studied cellulase producers [1]. The fungus Trichoderma reesei is an efficient producer of cellulase enzymes. Waste materials from a wide range of agroindustrial processes may be used as the substrates for microbial growth, thereby resulting in upgrading of the waste or the synthesis of valuable by-products. The bulks of the wastes from agriculture or food processing are not suitable for food or animal feed because they are too fibrous to be digested by monogastric animals [2], however, a significant proportion $(30-70 \%)$ of the dry weight of these wastes are carbohydrates other than cellulose and are therefore readily assimilable by microorganisms [3]. Production of cellulase enzyme in large quantities requires understanding and proper controlling of the growth and enzyme production capabilities of T. reesei. This is an extremely complicated system; many factors influence the organism's ability to grow and produce enzyme $[4,5]$. With the increasing demand for alternative liquid fuels worldwide, cellulase is being used as the primary enzyme for enzymatic hydrolysis of lignocellulosic biomass in bioethanol production process. It is known that the production economics of bioethanol is largely dependent on the cost of cellulase. However, high cost of the enzyme presents a significant barrier to the commercialization of bioethanol. Therefore, finding an economic way to produce cellulase has drawn great attention around the world [6]. The cost of enzymes is one of the main factors determining the economics of a biocatalytic process and it can be reduced by finding optimum conditions for their production. In order to minimize the enzymes' production cost, considerable progress has been made in strain development, optimization of culture condition, mode offermentation, and modelling the process [7]. Microorganisms are capable of utilizing the organic matter in wastes both as a source of energy for growth and as carbon for the synthesis of cell biomass [8-10].

During pineapple processing, the crown and stem are cut off before peeling. The core is then removed for further processing. These wastes (peel, core, stem, crown, and leaves) generally account for $50 \%(\mathrm{w} / \mathrm{w})$ of total pineapple weight. 
Therefore, with increasing pineapple production, pineapple wastes are also proportionally increasing. Waste disposal represents a growing problem since it is usually prone to microbial spoilage and it causes serious environmental problems. The utilization of waste would be an innovation to handle the great deal of waste from processing. Pineapple wastes are found to have potential uses as raw materials that can be converted into value-added products. In agricultural, waste is occasionally utilized as a fertilizer or animal feed. The peel is a rich source of cellulose, hemicelluloses, and other carbohydrates. It has been used to produce paper, banknotes, and cloth $[11,12]$.

The core waste could be used for the production of frozen pineapple juice concentrates or extracted juice for alcoholic beverages or for vinegar $[13,14]$. In addition, the waste from pineapple has been used as a nutrient substance in culture broth $[15,16]$ and cellulase production [17, 18]. Moreover, the pineapple wastes have also been used as substrates for the production of methane, ethanol, citric acid, and antioxidant compounds [19].

Lignin is an undesirable polymer and its removal during hydrolysis step requires high amount of energy and chemicals. Pineapple waste has relatively lower lignin content which suggests that these materials can undergo hydrolysis step more easily with the utilization of lesser amount of chemicals than other waste materials such as banana stem, coconut waste, and oil palm empty fruit bunches [20-22]. However, reports on the use of pineapple waste for the production of industrially relevant metabolites such as cellulase through fermentation processes are rare. Thus, cultivation of microorganisms on these wastes may be a value-added process capable of converting these materials, which are otherwise considered to be wastes, into valuable products through processes with technoeconomic feasibility. In the present study, the screening and optimization of medium composition for cellulase production by Trichoderma reesei using Plackett-Burman and Response Surface Methodology (RSM) were carried out. The Plackett-Burman screening design is applied for identifying the significant variables that enhance cellulase production. The central composite design (CCD) was further applied to determine the optimum level of each significant variable. To the best of our knowledge this is the first paper on cellulase production using pineapple waste as substrate by $T$. reesei and there is no literature available on the production of cellulase using the above substrate and microorganism so far.

\section{Materials and Methods}

2.1. Microorganisms. T. reesei NCIM 1186 was procured from National Collection of Industrial Microorganism (NCIM), National Chemical Laboratory, Pune, India, and maintained on potato dextrose agar (PDA) at $4^{\circ} \mathrm{C}$ for subsequent use as inoculum.

2.2. Inoculum Preparation. The fungal culture was grown on PDA slants and the spores were harvested aseptically from 5-day-old PDA slants. Sterile distilled water containing
TABle 1: Composition for pineapple waste.

\begin{tabular}{lc}
\hline Composition & Percentage (\%) \\
\hline Extractive & 5.5 \\
Holocellulose & 80.5 \\
Lignin & 10.5 \\
Ash & 2.0 \\
Others & 1.5 \\
\hline
\end{tabular}

$0.1 \%(\mathrm{w} / \mathrm{v})$ Tween-80 was added to each fungal slant and vortexed. Spore count was measured with haemocytometer and adjusted to $2 \times 10^{6}$ spores/mL by adjustment of optical density.

2.3. Substrate Preparation and Sterilization. Pineapple wastes were collected from the local market at Chidambram, Tamilnadu, India. The collected raw materials are dried in sunlight for 2 days, crushed, and sieved for different mesh size ranging from $0.45 \mathrm{~mm}$ to $0.9 \mathrm{~mm}$ (20-40 mesh) and used for further studies. The composition of pineapple waste (peel, core, crown, and stem) is given in Table 1 which is used for cellulase production.

The pretreatment process decreases the crystallinity of pineapple waste while removing lignin and other inhibitors thereby enabling its enzymatic hydrolysis. $100 \mathrm{~g}$ of the washed ground pineapple waste was treated separately with $2000 \mathrm{~mL}$ of $2 \% \mathrm{NaOH}$ solution and autoclaved at $121^{\circ} \mathrm{C}$ for $30 \mathrm{~min}$. Then it was filtered, washed with distilled water, and excess alkali present was neutralized with phosphoric acid. Again it was filtered and the residue material was dried at $65^{\circ} \mathrm{C}$ in a hot air oven to constant weight. To the cellulosic material obtained, the same volume of distilled water was added and heated at $121^{\circ} \mathrm{C}$ for $30 \mathrm{~min}$. The suspension was filtered and the solid material was dried at $65^{\circ} \mathrm{C}$ to constant weight in hot air oven [23]. The dried pineapple powder was used as a carbon source.

2.4. Enzyme Production under Submerged Fermentation. Fermentation was carried out in Erlenmeyer flasks $(250 \mathrm{~mL})$ with $10 \mathrm{~g}$ of pretreated pineapple waste powder, supplemented with nutrients' concentration defined by the experimental design. Each flask was covered with hydrophobic cotton and autoclaved at $120^{\circ} \mathrm{C}$ for $20 \mathrm{~min}$. After cooling, the flasks were inoculated at room temperature and maintained at $30^{\circ} \mathrm{C}$ at $200 \mathrm{rpm}$ for 48 hours. During the preliminary screening process, the experiments were carried out for 9 days and it was found that the maximum production of cellulase was obtained on the 6th day of fermentation.

2.5. Determination of Enzyme Activity. Cellulase activity (FPA) was analyzed on filter paper, according to Ghose [24]. One unit of enzyme corresponds to the amount of enzyme necessary to form $1 \mu \mathrm{mol}$ of glucose per $\mathrm{mL}$ per minute. The reducing sugars were measured by the dinitrosalicylic acid (DNS) method according to Miller [25]. 
Table 2: Nutrients screening using Plackett-Burman design.

\begin{tabular}{|c|c|c|c|c|}
\hline S. Number & Nutrients code & Nutrient & Minimum value $\mathrm{g} / \mathrm{L}$ & Maximum value $\mathrm{g} / \mathrm{L}$ \\
\hline 1 & A & Avicel & 15 & 35 \\
\hline 2 & B & Corn steep flour & 2 & 8 \\
\hline 3 & $\mathrm{C}$ & $\mathrm{MnSO}_{4} \cdot \mathrm{H}_{2} \mathrm{O}$ & 0.6 & 1.2 \\
\hline 4 & $\mathrm{D}$ & $\mathrm{FeSO}_{4} \cdot 7 \mathrm{H}_{2} \mathrm{O}$ & 0.7 & 1.3 \\
\hline 5 & $\mathrm{E}$ & Beef extract & 20 & 40 \\
\hline 6 & $\mathrm{~F}$ & Soybean cake flour & 10 & 30 \\
\hline 7 & G & $\mathrm{KH}_{2} \mathrm{PO}_{4}$ & 2 & 6 \\
\hline 8 & $\mathrm{H}$ & $\mathrm{CoCl}_{2} \cdot 6 \mathrm{H}_{2} \mathrm{O}$ & 0.5 & 1 \\
\hline 9 & I & Yeast extract & 5 & 15 \\
\hline
\end{tabular}

\subsection{Optimization of Cellulase Production}

2.6.1. Plackett-Burman Experimental Design. Plackett-Burman experimental design assumes that there are no interactions between the different variables in the range under consideration. A linear approach is considered to be sufficient for screening. Plackett-Burman experimental design is a fractional factorial design and the main effects of such a design may be simply calculated as the difference between the average of measurements made at the high level $(+1)$ of the factor and the average of measurements at the low level $(-1)$.

To determine that the variables significantly affect cellulase activity, Plackett-Burman design is used. Nine variables (Table 2) are screened in 20 experimental runs (Table 3) and insignificant ones are eliminated in order to obtain a smaller, manageable set of factors. The low level $(-1)$ and high level $(+1)$ of each factor are listed in (Table 2). The statistical software package, Design-Expert software (version 7.1.5, Stat-Ease, Inc., Minneapolis, USA), is used for analysing the experimental data. Once the critical factors are identified through the screening, the central composite design (CCD) is used to obtain a quadratic model.

2.6.2. Central Composite Design. The central composite design is used to study the effects of variables on their responses and subsequently in the optimization studies. This method is suitable for fitting a quadratic surface and it helps to optimize the effective parameters with minimum number of experiments as well as to analyse the interaction between the parameters. In order to determine the existence of a relationship between the factors and response variables, the collected data were analysed in a statistical manner, using regression. A regression design is normally employed to model a response as a mathematical function (either known or empirical) of a few continuous factors and good model parameter estimates are desired.

The coded values of the process parameters are determined by the following equation:

$$
x_{i}=\frac{X_{i}-X_{0}}{\Delta x},
$$

where $x_{i}$ is the coded value of the $i$ th variable, $X_{i}$ is the uncoded value of the $i$ th test variable, $X_{0}$ is the uncoded value of the $i$ th test variable at centre point, and $\Delta x$ is the step change. The regression analysis is performed to estimate the response function as a second-order polynomial:

$$
Y=\beta_{0}+\sum_{i=1}^{k} \beta_{i} X_{i}+\sum_{i=1}^{k} \beta_{i i} X_{i}^{2}+\sum_{i=1, i<j}^{k-1} \sum_{j=2}^{k} \beta_{i j} X_{i} X_{j},
$$

where $Y$ is the predicted response, $\beta_{0}$ constant, and $\beta_{i}, \beta_{j}$, $\beta_{i j}$ are coefficients estimated from regression. They represent the linear, quadratic, and cross products of $X_{i}$ and $X_{j}$ on response.

Model fitting and statistical analysis and the regression and graphical analysis with statistical significance are carried out using Design-Expert software (version 7.1.5, Stat-Ease, Inc., Minneapolis, USA). The minimum and maximum ranges of variables investigated are listed in (Table 4). In order to visualize the relationship between the experimental variables and responses, the response surface and contour plots are generated from the models. The optimum values of the process variables are obtained from the regression equation.

The adequacy of the models is further justified through analysis of variance (ANOVA). Lack-of-fit is a special diagnostic test for adequacy of a model and compares the pure error, based on the replicate measurements to the other lackof-fit, based on the model performance. $F$-value, calculated ratio between the lack-of-fit mean square and the pure error mean square, this statistic parameters are used to determine whether the lack-of-fit is significant or not, at a significance level.

\section{Results and Discussion}

Plackett-Burman experiments (Table 3) showed a wide variation in cellulase production. This variation reflected the importance of optimization to attain higher productivity. From the pareto chart (Figure 1) the variables, namely, Avicel, soybean cake flour, $\mathrm{KH}_{2} \mathrm{PO}_{4}$, and yeast extract, were found to be significant, while corn steep flour, $\mathrm{MnSO}_{4} \cdot \mathrm{H}_{2} \mathrm{O}$, $\mathrm{FeSO}_{4} \cdot 7 \mathrm{H}_{2} \mathrm{O}$, beef extract, and $\mathrm{CoCl}_{2} \cdot \mathrm{H}_{2} \mathrm{O}$ were considered nonsignificant ones. Hence avicel, soybean cake flour, $\mathrm{KH}_{2} \mathrm{PO}_{4}$, and yeast extract were selected for further optimization to attain a maximum response. 
TABLE 3: Plackett-Burman experimental design for nine variables.

\begin{tabular}{|c|c|c|c|c|c|c|c|c|c|c|}
\hline Run order & $\mathrm{A}$ & $\mathrm{B}$ & $\mathrm{C}$ & $\mathrm{D}$ & $\mathrm{E}$ & $\mathrm{F}$ & $\mathrm{G}$ & $\mathrm{H}$ & $\mathrm{I}$ & Cellulase activity IU/mL \\
\hline 1 & 1 & -1 & -1 & 1 & 1 & -1 & 1 & 1 & -1 & 6.5 \\
\hline 2 & 1 & -1 & 1 & -1 & 1 & 1 & 1 & 1 & -1 & 7.5 \\
\hline 3 & 1 & 1 & 1 & -1 & -1 & 1 & 1 & -1 & 1 & 8.5 \\
\hline 4 & -1 & -1 & -1 & -1 & 1 & -1 & 1 & -1 & 1 & 4.5 \\
\hline 5 & 1 & 1 & -1 & -1 & 1 & 1 & -1 & 1 & 1 & 6.9 \\
\hline 6 & 1 & 1 & 1 & 1 & -1 & -1 & 1 & 1 & -1 & 7.7 \\
\hline 7 & -1 & -1 & 1 & -1 & 1 & -1 & 1 & 1 & 1 & 5.7 \\
\hline 8 & 1 & -1 & -1 & -1 & -1 & 1 & -1 & 1 & -1 & 5 \\
\hline 9 & 1 & 1 & -1 & -1 & -1 & -1 & 1 & -1 & 1 & 7 \\
\hline 10 & -1 & 1 & -1 & 1 & 1 & 1 & 1 & -1 & -1 & 6.3 \\
\hline 11 & -1 & -1 & 1 & 1 & -1 & 1 & 1 & -1 & -1 & 5.4 \\
\hline 12 & 1 & 1 & -1 & 1 & 1 & -1 & -1 & -1 & -1 & 4.9 \\
\hline 13 & -1 & -1 & -1 & 1 & -1 & 1 & -1 & 1 & 1 & 6.1 \\
\hline 14 & -1 & 1 & 1 & -1 & 1 & 1 & -1 & -1 & -1 & 5.5 \\
\hline 15 & -1 & 1 & -1 & 1 & -1 & 1 & 1 & 1 & 1 & 7.8 \\
\hline 16 & -1 & 1 & 1 & -1 & -1 & -1 & -1 & 1 & -1 & 4.1 \\
\hline 17 & -1 & -1 & -1 & -1 & -1 & -1 & -1 & -1 & -1 & 2.9 \\
\hline 18 & -1 & 1 & 1 & 1 & 1 & -1 & -1 & 1 & 1 & 4.5 \\
\hline 19 & 1 & -1 & 1 & 1 & -1 & -1 & -1 & -1 & 1 & 5.7 \\
\hline 20 & 1 & -1 & 1 & 1 & 1 & 1 & -1 & -1 & 1 & 8 \\
\hline
\end{tabular}

TABLE 4: Ranges of variables used in RSM.

\begin{tabular}{lcccccc}
\hline Variables $(\mathrm{g} / \mathrm{L})$ & Code & -2 & -1 & 0 & +1 & +2 \\
\hline Avicel & A & 15 & 20 & 25 & 30 & 35 \\
Soybean cake flour & B & 10 & 15 & 3 & 4 & 30 \\
$\mathrm{KH}_{2} \mathrm{PO}_{4}$ & $\mathrm{C}$ & 2 & 7.5 & 10 & 5 \\
Yeast extract & $\mathrm{D}$ & 5 & 12.5 & 6 \\
\hline
\end{tabular}

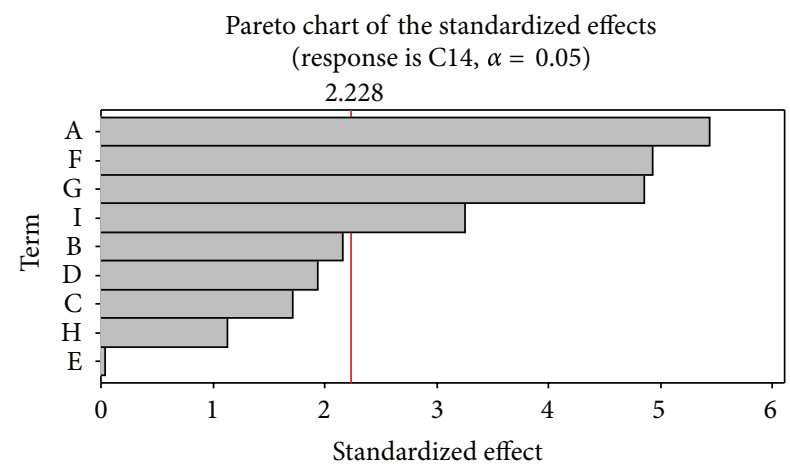

FIGURE 1: Pareto chart showing the effect of media components on Cellulase activity (A-Avicel, F-Soybean cake flour, $\mathrm{G}-\mathrm{KH}_{2} \mathrm{PO}_{4}$, and I-Yeast extract).

The level of factors avicel, soybean cake flour, $\mathrm{KH}_{2} \mathrm{PO}_{4}$, and yeast extract and the effect of their interactions on cellulase production were determined by central composite design of RSM. Thirty experiments were preferred at different combinations of the factors shown in (Table 5) and the central point was repeated four times $(8,17,20$, and 26$)$.
The predicted and observed responses along with design matrix are presented in (Table 5); the results were analysed by ANOVA.

The second-order regression equation provided the levels of cellulase activity as a function of avicel, soybean cake flour, $\mathrm{KH}_{2} \mathrm{PO}_{4}$, and yeast extract, which can be presented in terms of coded factors as in the following equation:

$$
\begin{aligned}
Y= & 8.57143+0.53750 \mathrm{~A}+0.39000 \mathrm{~B}+0.31500 \mathrm{C} \\
& +0.81250 \mathrm{D}-0.71390 \mathrm{~A} * \mathrm{~A} \\
& -0.66015 \mathrm{~B} * \mathrm{~B}-0.056015 \mathrm{C} * \mathrm{C} \\
& -0.55140 \mathrm{D} * \mathrm{D}-0.05625 \mathrm{~A} * \mathrm{~B} \\
& +0.03125 \mathrm{~A} * \mathrm{C}+0.08125 \mathrm{~A} * \mathrm{D} \\
& +0.08125 \mathrm{~B} * \mathrm{C}+0.29375 \mathrm{~B} * \mathrm{D} \\
& +0.20625 \mathrm{C} * \mathrm{D}
\end{aligned}
$$

where $Y$ is the cellulase yield $(\mathrm{IU} / \mathrm{mL}), \mathrm{A}, \mathrm{B}, \mathrm{C}$, and $\mathrm{D}$ are avicel, soybean cake flour, $\mathrm{KH}_{2} \mathrm{PO}_{4}$, and yeast extract, respectively. ANOVA for the response surface is shown 
TABle 5: Central composite design in coded levels with cellulase yield as response.

\begin{tabular}{|c|c|c|c|c|c|c|}
\hline Run order & A & $\mathrm{F}$ & $\mathrm{G}$ & $\mathrm{I}$ & Experimental cellulase activity IU/mL & Predicted cellulase activity IU/mL \\
\hline 1 & -1 & 1 & -1 & 1 & 5.8 & 6.61 \\
\hline 2 & 0 & 0 & 0 & 2 & 7.8 & 7.99 \\
\hline 3 & -1 & -1 & -1 & 1 & 4.6 & 5.29 \\
\hline 4 & 1 & -1 & -1 & -1 & 5.7 & 5.79 \\
\hline 5 & 0 & 0 & 0 & -2 & 6.1 & 4.74 \\
\hline 6 & 0 & -2 & 0 & 0 & 5.7 & 5.15 \\
\hline 7 & 1 & 1 & -1 & 1 & 5.9 & 7.34 \\
\hline 8 & 0 & 0 & 0 & 0 & 8.6 & 8.57 \\
\hline 9 & 1 & -1 & 1 & -1 & 5.4 & 5.91 \\
\hline 10 & 0 & 0 & 0 & 0 & 8.5 & 8.57 \\
\hline 11 & 0 & 2 & 0 & 0 & 7.5 & 6.71 \\
\hline 12 & 1 & 1 & 1 & 1 & 8.2 & 8.61 \\
\hline 13 & 1 & -1 & -1 & 1 & 6.5 & 6.25 \\
\hline 14 & 0 & 0 & 2 & 0 & 8.1 & 6.96 \\
\hline 15 & -1 & 1 & 1 & 1 & 7.8 & 7.75 \\
\hline 16 & -1 & 1 & 1 & -1 & 6.1 & 4.96 \\
\hline 17 & 0 & 0 & 0 & 0 & 8.6 & 8.57 \\
\hline 18 & -1 & -1 & 1 & -1 & 4.7 & 4.49 \\
\hline 19 & -2 & 0 & 0 & 0 & 5.2 & 4.64 \\
\hline 20 & 0 & 0 & 0 & 0 & 8.6 & 8.57 \\
\hline 21 & 0 & 0 & 0 & 0 & 8.5 & 8.57 \\
\hline 22 & 1 & -1 & 1 & 1 & 7.1 & 7.19 \\
\hline 23 & -1 & -1 & -1 & -1 & 4.3 & 4.50 \\
\hline 24 & 2 & 0 & 0 & 0 & 6.9 & 6.79 \\
\hline 25 & 1 & 1 & -1 & -1 & 5.6 & 5.71 \\
\hline 26 & 0 & 0 & 0 & 0 & 8.6 & 8.57 \\
\hline 27 & 0 & 0 & -2 & 0 & 5.8 & 5.70 \\
\hline 28 & 1 & 1 & 1 & -1 & 6.5 & 6.15 \\
\hline 29 & -1 & -1 & 1 & 1 & 5.6 & 6.11 \\
\hline 30 & -1 & 1 & -1 & -1 & 4.7 & 4.64 \\
\hline
\end{tabular}

in Table 6. The model $F$ value of 17.23 implies the model is significant. There is only a $0.01 \%$ chance that a "Model $F$ value" this large could occur due to noise. Values of "prob $>F$ " less than 0.05 indicate that model terms are significant. Values greater than 0.1 indicate that model terms are not significant. In the present work, linear terms of $\mathrm{A}, \mathrm{B}, \mathrm{C}$, and $\mathrm{D}$ and all the square effects of $A, B, C$, and D and the interaction effect of $\mathrm{B} * \mathrm{C}$ were found to be significant for the production of cellulase. The coefficient of determination $\left(R^{2}\right)$ for cellulase activity was calculated as 0.94 , which is very close to 1 and can explain up to $94.00 \%$ variability of the response. The predicted $R^{2}$ value of 0.86 was in reasonable agreement with the adjusted $R^{2}$ value of 0.76 . An adequate precision value greater than 4 is desirable. The adequate precision value of 11.94 indicates an adequate signal and suggests that the model can navigate the design space.

The interactive effects of variables on cellulase production were studied by $3 \mathrm{D}$ response surface plots against any two independent variables and its respective cellulase production, while keeping other variables at its central (0) level. The 3D curves of the calculated response (cellulase production) and

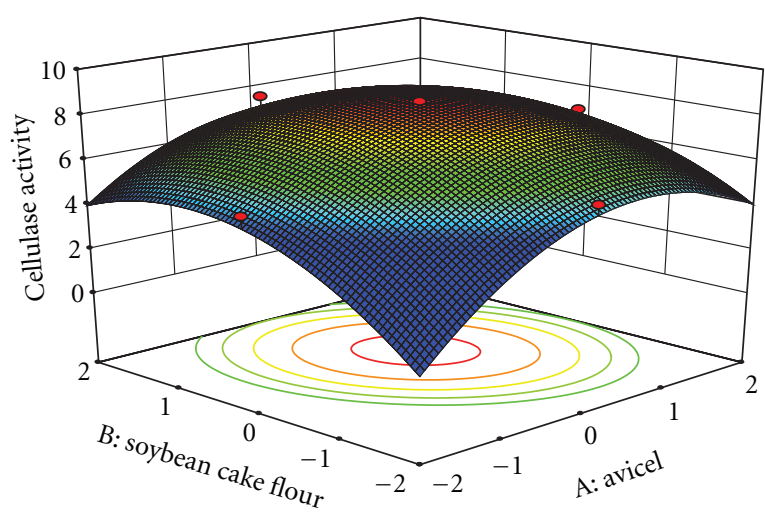

FIGURE 2: 3D plot showing the effect of avicel and soybean cake flour on cellulase activity.

contour plots from the interactions between the variables were shown in Figures 2, 3, 4, 5, 6, and 7.

During the fermentation period, the carbon source was found to be the major constituent for the synthesis 
TABLE 6: Analyses of variance (ANOVA) for response surface quadratic model for the production of cellulose.

\begin{tabular}{|c|c|c|c|c|c|}
\hline Source & Sum of square & $\mathrm{df}$ & Mean square value & $F$ value & $P$ value \\
\hline Model & 54.46 & 14 & 3.89 & 17.23 & $<0.0001$ \\
\hline A-Avicel & 4.77 & 1 & 4.77 & 21.13 & 0.003 \\
\hline B-Soybean cake flour & 4.42 & 1 & 4.42 & 19.58 & 0.0005 \\
\hline $\mathrm{C}-\mathrm{KH}_{2} \mathrm{PO}_{4}$ & 6.93 & 1 & 6.93 & 30.72 & $<0.0001$ \\
\hline D-Yeast extract & 5.90 & 1 & 5.90 & 26.14 & 0.0001 \\
\hline $\mathrm{AB}$ & 0.86 & 1 & 0.86 & 3.79 & 0.0705 \\
\hline $\mathrm{AC}$ & 0.11 & 1 & 0.11 & 0.47 & 0.5044 \\
\hline $\mathrm{AD}$ & 0.016 & 1 & 0.016 & 0.069 & 0.7961 \\
\hline $\mathrm{BC}$ & 1.50 & 1 & 1.50 & 6.65 & 0.0120 \\
\hline $\mathrm{BD}$ & 0.076 & 1 & 0.076 & 0.34 & 0.5713 \\
\hline $\mathrm{CD}$ & 0.77 & 1 & 0.77 & 3.39 & 0.0854 \\
\hline$A^{2}$ & 15.47 & 1 & 15.47 & 68.54 & $<0.0001$ \\
\hline $\mathrm{B}^{2}$ & 10.33 & 1 & 10.33 & 45.74 & $<0.0001$ \\
\hline$C^{2}$ & 7.59 & 1 & 7.59 & 33.63 & $<0.0001$ \\
\hline $\mathrm{D}^{2}$ & 7.59 & 1 & 7.59 & 33.63 & $<0.0001$ \\
\hline Residual & 3.39 & 15 & 0.23 & & \\
\hline Lack of fit & 3.37 & 10 & 0.34 & 126.47 & $<0.0001$ \\
\hline Pure error & 0.013 & 5 & $2.66 E-003$ & & \\
\hline Cor total & 57.85 & 29 & & & \\
\hline
\end{tabular}

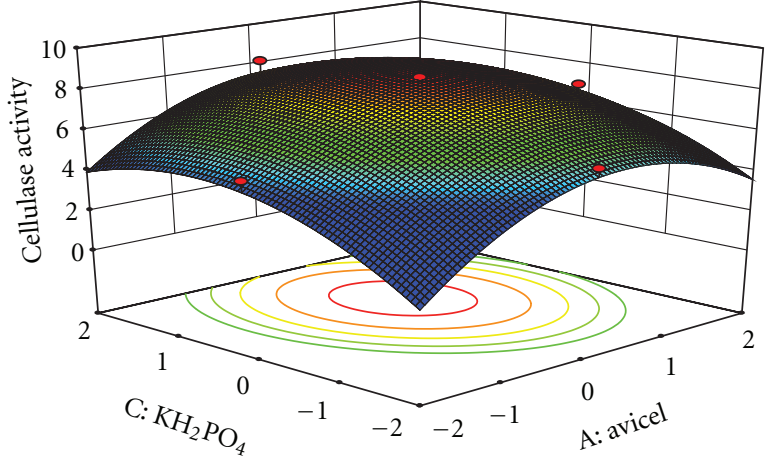

FIGURE 3: $3 \mathrm{D}$ plot showing the effect of avicel and $\mathrm{KH}_{2} \mathrm{PO}_{4}$ on cellulase activity.

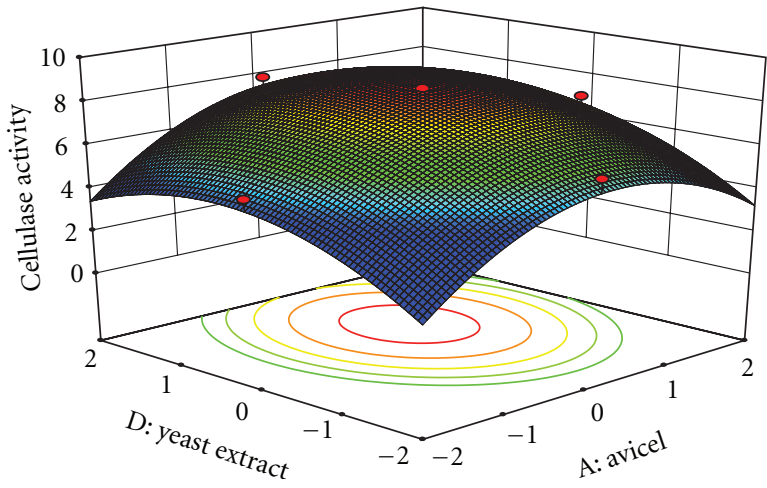

FIGURE 4: 3D plot showing the effect of avicel and yeast extract on cellulase activity.

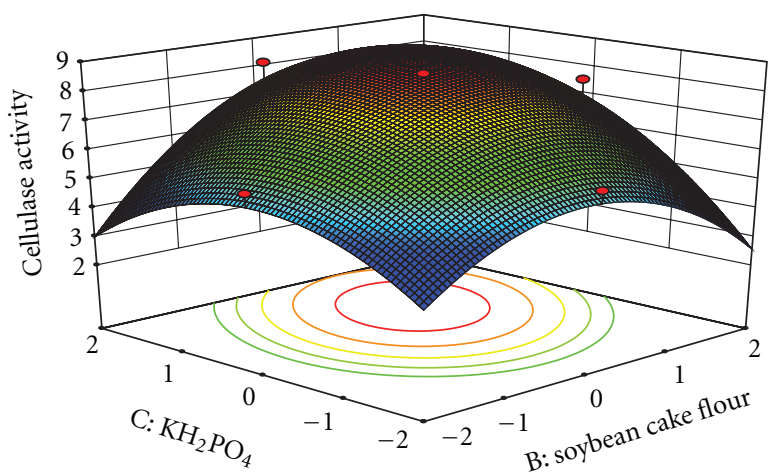

FIGURE 5: 3D plot showing the effect of soybean cake flour and $\mathrm{KH}_{2} \mathrm{PO}_{4}$ on cellulase activity.

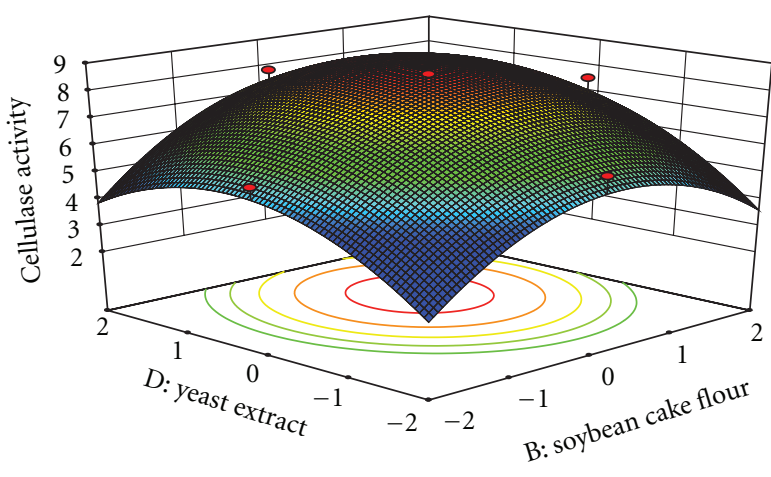

FIGURE 6: 3D plot showing the effect of soybean cake flour and yeast extract on cellulase activity. 


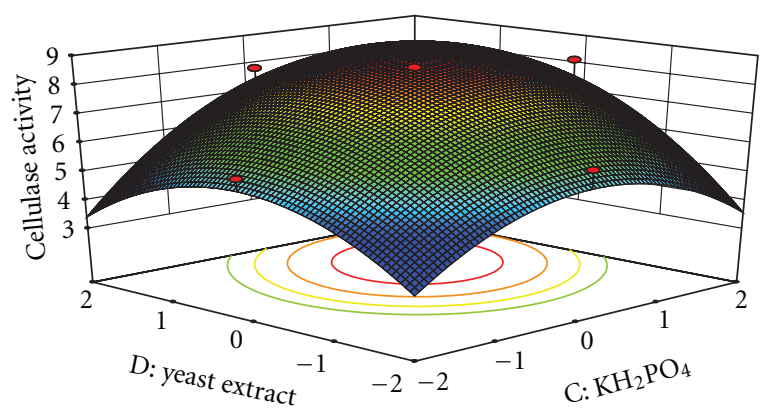

Figure 7: 3D plot showing the effect of $\mathrm{KH}_{2} \mathrm{PO}_{4}$ and yeast extract on cellulase activity.

of cellulase. The effect of carbon source (avicel) on cellulase production has been shown in Figure 2 in which the cellulase activity is increased with increase in avicel concentration of $26.59 \mathrm{~g} / \mathrm{L}$ and thereafter cellulase activity decreased with further increase in avicel concentration. The same trend was observed in Figure 3 in which it is clear that avicel aided in the production of cellulase. Similar results were reported by Hao et al. [26].

The increase in the concentration of soybean cake flour resulted in increase in the cellulase activity up to $22.59 \mathrm{~g} / \mathrm{L}$, which is shown in Figures 2 and 5. Figures 3 and 5 show the dependency of cellulase activity on $\mathrm{KH}_{2} \mathrm{PO}_{4} \cdot \mathrm{KH}_{2} \mathrm{PO}_{4}$ has a strong positive linear effect on the production of cellulase. These results are in agreement with results reported by Anuradha Jabasingh [27].

The maximum cellulase activity was observed at $4.59 \mathrm{~g} / \mathrm{L}$ of $\mathrm{KH}_{2} \mathrm{PO}_{4}$. Figures 6 and 7 show the dependency of cellulase activity on yeast extract. The organic nitrogen source, yeast extract used in the study favoured the synthesis of cellulases using T. reesei in pineapple waste. The supplementation of organic and inorganic nitrogen sources stimulated the cellulase yield and activity. Use of organic $\mathrm{N}$ sources responded to the positive cellulase activity more than the inorganic ones. The results obtained are in accordance with the results of Ray et al. who reported that organic nitrogen sources were found to be more suitable for optimizing cellulase production by Bacillus subtilis and Bacillus circulans than inorganic sources [28]. A maximum cellulase activity was observed at $12.3 \mathrm{~g} / \mathrm{L}$ of yeast extract.

\section{Validation of the Experimental Model}

Validation of the experimental model was tested by carrying out the batch experiment under optimal media compositions: avicel: $26.51 \mathrm{~g} / \mathrm{L}$, soybean cake flour: $22.52 \mathrm{~g} / \mathrm{L}, \mathrm{KH}_{2} \mathrm{PO}_{4}$ : $4.50 \mathrm{~g} / \mathrm{L}$, and yeast extract: $12.3 \mathrm{~g} / \mathrm{L}$ established by the regression model. Four parallel experiments were performed in the optimized media and the results are compared. The maximum cellulase activity $(8.61 \mathrm{IU} / \mathrm{mL})$ was obtained from experiments which was very close to the cellulase production $(8.56 \mathrm{IU} / \mathrm{mL})$ predicted by the regression model, which proved the validity of the model.

\section{Conclusion}

In this work, Plackett-Burman design was used to determine the relative importance of medium components for cellulase production. Among the variables, avicel, soybean cake flour, $\mathrm{KH}_{2} \mathrm{PO}_{4}$, and yeast extract were found to be the most significant variables. From further optimization studies the optimized values of the variables for maximum cellulase activity were as follows: avicel- $26.51 \mathrm{~g} / \mathrm{L}$, soybean cake flour$22.52 \mathrm{~g} / \mathrm{L}, \mathrm{KH}_{2} \mathrm{PO}_{4}-4.50 \mathrm{~g} / \mathrm{L}$, and yeast extract- $12.37 \mathrm{~g} / \mathrm{L}$. This study showed that the pineapple waste is a good source for the production of cellulase. The maximum production of $8.61 \mathrm{IU} / \mathrm{mL}$ of cellulase production was obtained under the optimized media. The results show a close concordance between the predicted and the experimental run.

\section{References}

[1] S. B. Riswanali, P. Saravanan, R. Muthuvelayudham, and T. Viruthagiri, "Optimization of nutrient medium for cellulase and hemicellulase productions from rice straw: a statistical approach," International Journal of Chemical and Analytical Science, vol. 3, no. 4, pp. 1364-1370, 2012.

[2] G. G. Birch, N. Blakebrough, and K. J. Parker, Enzymes and Food Processing, Applied Science, London, UK, 1981.

[3] A. J. Forage, "III. Utilization of agricultural and food processing wastes containing carbohydrates," Chemical Society Reviews, vol. 8, no. 2, pp. 309-314, 1979.

[4] A. Tholudur, F. Ramirez, and D. James McMillan, "Mathematical modeling and optimization of cellulase protein production using Trichoderma reesei RL-P37," Biotechnology and Bioengineering, vol. 66, no. 1, pp. 1-16, 1999.

[5] Y. Sun and J. Cheng, "Hydrolysis of lignocellulosic materials for ethanol production: a review," Bioresource Technology, vol. 83, no. 1, pp. 1-11, 2002.

[6] R. Soni, A. Nazir, and B. S. Chadha, "Optimization of cellulase production by a versatile Aspergillus fumigatus fresenius strain (AMA) capable of efficient deinking and enzymatic hydrolysis of Solka floc and bagasse," Industrial Crops and Products, vol. 31, no. 2, pp. 277-283, 2010.

[7] S. B. Riswan Ali, R. Muthuvelayudham, and T. Viruthagiri, "Statistical optimization of nutrients for production cellulase \& hemicellulase from rice straw," Asian Journal of Biochemical and Pharmaceutical Research, vol. 2, pp. 154-174, 2012.

[8] J. T. Worgan, "Waste from crop plants as raw materials for conversion by fungi to food or livestock feed," in Food From Waste, pp. 23-41, Applied Science, London, UK.

[9] S. Kim and B. E. Dale, "Global potential bioethanol production from wasted crops and crop residues," Biomass and Bioenergy, vol. 26, no. 4, pp. 361-375, 2004.

[10] G. A. Youssef and M. M. Berekaa, "Improved production of endoglucanase enzyme by Aspergillus terreus; Application of Plackett-Burman design for optimization of process parameters," Biotechnology, vol. 8, no. 2, pp. 212-219, 2009.

[11] A. P. Bartolomé, P. Rupérez, and C. Fúster, "Pineapple fruit: morphological characteristics, chemical composition and sensory analysis of Red Spanish and Smooth Cayenne cultivars," Food Chemistry, vol. 53, no. 1, pp. 75-79, 1995.

[12] A. U. Mahmood, J. Greenman, and A. H. Scragg, "Orange and potato peel extracts: analysis and use as Bacillus substrates for the production of extracellular enzymes in continuous culture," 
Enzyme and Microbial Technology, vol. 22, no. 2, pp. 130-137, 1998.

[13] R. Thanong, "Utilization pineapple waste for frozen pineapple concentrate," Kasetsart University Journal, vol. 19, pp. 101-109, 1985.

[14] S. R. Couto and M. A. Sanromán, "Application of solidstate fermentation to food industry-A review," Journal of Food Engineering, vol. 76, no. 3, pp. 291-302, 2006.

[15] J. N. Nigam, "Single cell protein from pineapple cannery effluent," World Journal of Microbiology and Biotechnology, vol. 14, no. 5, pp. 693-696, 1998.

[16] J. F. Morton, "Optimization of cellulase production by Aspergillus niger and Tricoderma viride using sugar cane waste," Fruits of Warm Climates, pp. 18-28, 1987.

[17] P. Omojasola, J. Folakemi, P. Omowumi, and S. A. Ibiyemi, "Cellulase production by some fungi cultured on pineapplewaste," Nature and Science, vol. 6, pp. 64-81, 2008.

[18] J. N. Nigam, "Continuous ethanol production from pineapple cannery waste using immobilized yeast cells," Journal of Biotechnology, vol. 80, no. 2, pp. 189-193, 2000.

[19] K. Tanaka, Z. D. Hilary, and A. Ishizaki, "Investigation of the utility of pineapple juice and pineapple waste material as low-cost substrate for ethanol fermentation by Zymomonas mobilis," Journal of Bioscience and Bioengineering, vol. 87, no. 5, pp. 642-646, 1999.

[20] A. Khalil, "Application of central composite design based response surface methodology in parameter optimization and on cellulase production using agricultural waste," Bio Resources, vol. 1, no. 2, pp. 220-232, 2006.

[21] AJuwaied, A. Al-amiery, Z. Abdumuniem, and U. Anaam, "Studies on the production and application of cellulase from Trichoderma reesei QM- 9414," Journal of Yeast and Fungal Research, vol. 2, pp. 19-123, 2011.

[22] V. S. Bisaria and T. K. Ghose, "Biodegradation of cellulosic materials: substrates, microorganisms, enzymes and products," Enzyme and Microbial Technology, vol. 3, no. 2, pp. 90-104, 1981.

[23] R. Muthuvelayudham and T. Viruthagiri, "Application of central composite design based response surface methodology in parameter optimization and on cellulase production using agricultural waste," International Journal of Chemical and Biological Engineering, vol. 3, no. 2, pp. 97-104, 2010.

[24] T. K. Ghose, "Measurement of cellulase activities," Pure and Applied Chemistry, vol. 59, pp. 257-268, 1987.

[25] G. L. Miller, "Use of dinitrosalicylic acid reagent for determination of reducing sugar," Analytical Chemistry, vol. 31, no. 3, pp. 426-428, 1959.

[26] X. C. Hao, X. B. Yu, and Z. L. Yan, "Optimization of the medium for the production of cellulase by the mutant Trichoderma reesei WX-112 using response surface methodology," Food Technology and Biotechnology, vol. 44, no. 1, pp. 89-94, 2006.

[27] S. Anuradha Jabasingh and C. Valli Nachiyar, "A new combinational statistical approach for cellulase optimization in Aspergillus nidulans," Indian Journal of Science and Technology, vol. 3, no. 8, pp. 871-878, 2010.

[28] A. K. Ray, A. Bairagi, K. Sarkar Ghosh, and S. K. Sen, "Optimization of fermentation conditions for cellulase production by Bacillus subtilis CY5 and Bacillus circulans TP3 isolated from fish gut," Acta Ichthyologica et Piscatoria, vol. 37, no. 1, pp. 47-53, 2007. 

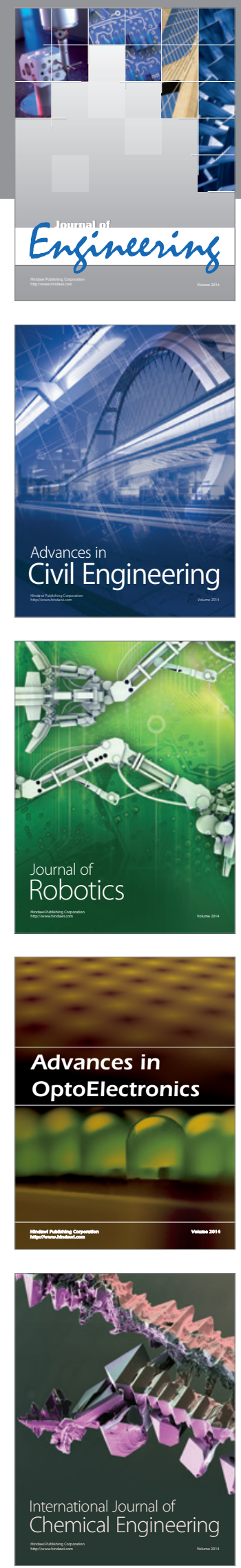

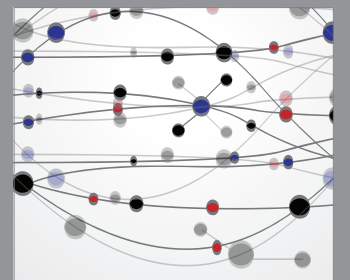

The Scientific World Journal
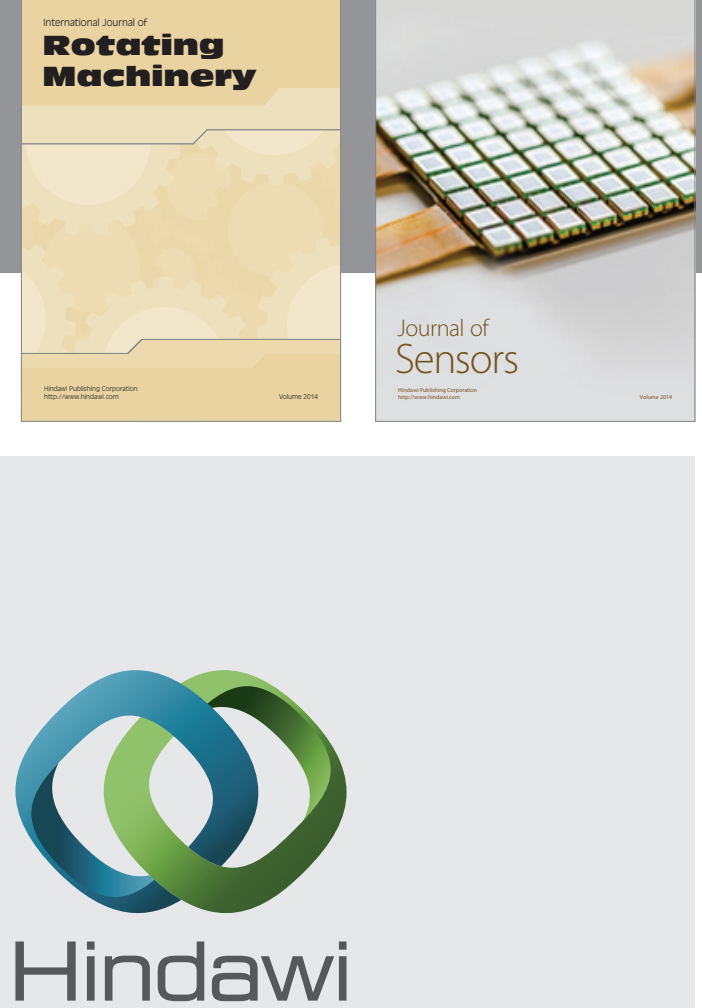

Submit your manuscripts at http://www.hindawi.com
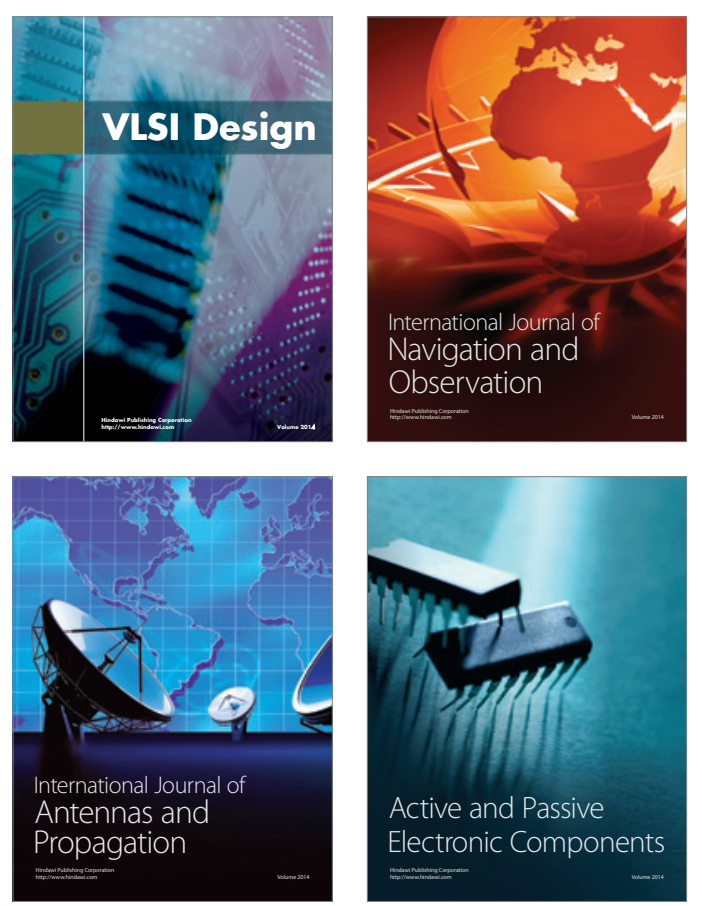
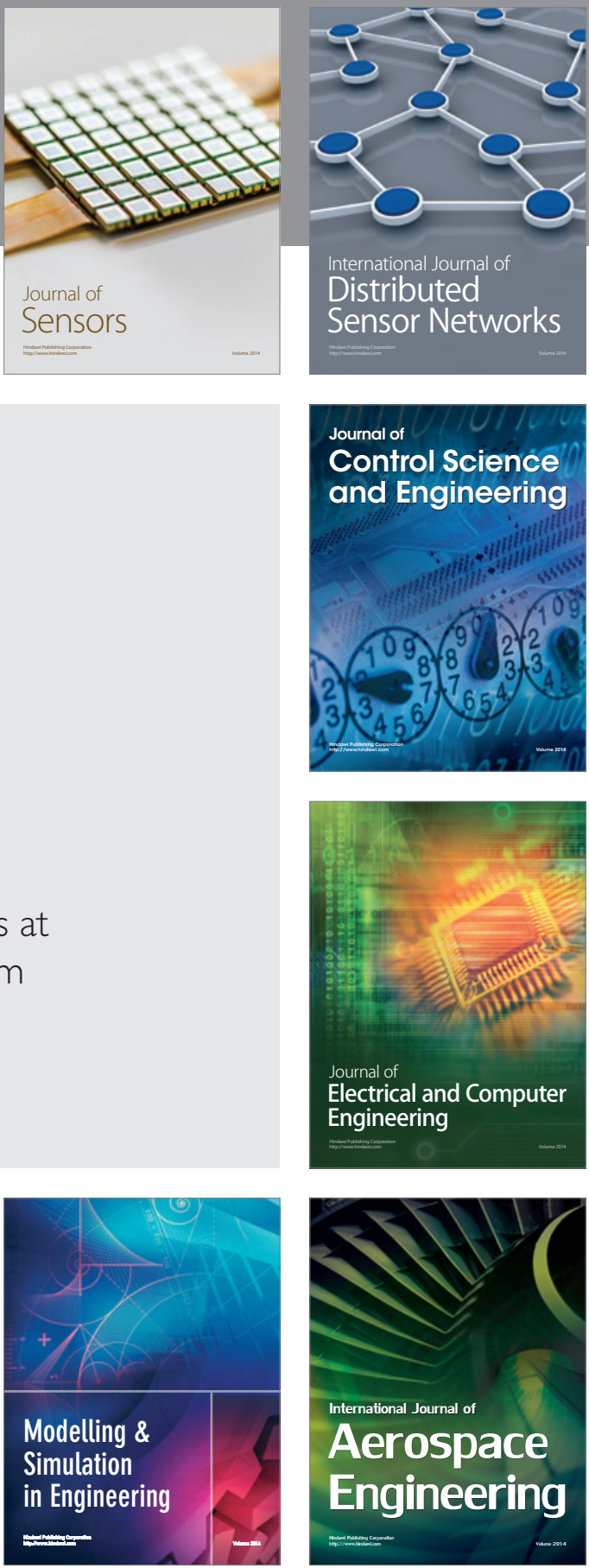

Journal of

Control Science

and Engineering
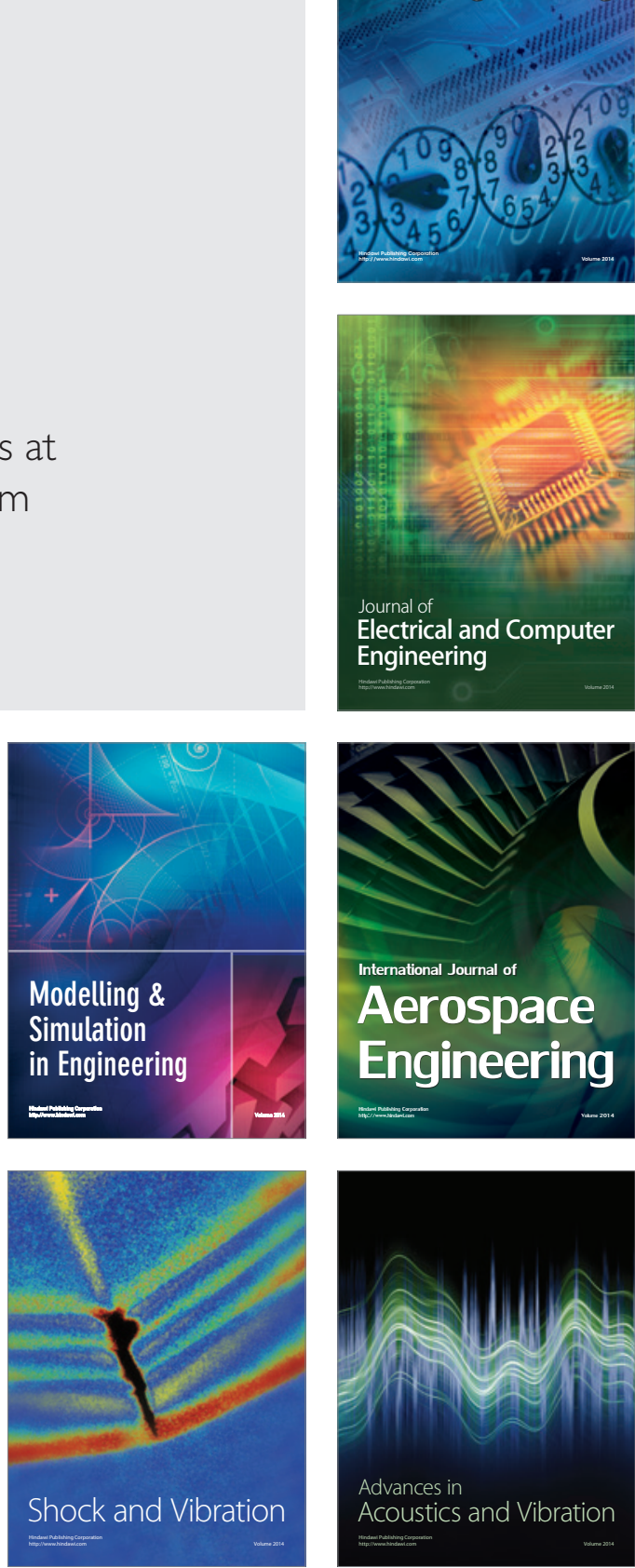